\title{
QUÍMICA SUSTENTÁVEL
}

É interessante observar como os temas e paradigmas avançam na sociedade e dentro da comunidade científica. Algumas vezes avançam de forma mais rápida porque são mais facilmente entendidos pelos responsáveis em traçar políticas e planejar ações e outras vezes mais lentamente e, mesmo assim, dependem de ação indutiva de ONGs, Sociedades Científicas e órgãos governamentais. Neste sentido, dois temas interrelacionados vêm sendo discutidos e consolidados nos últimos anos: a Sustentabilidade e a Química Verde. O tema Sustentabilidade $^{1}$ tem conotações muito mais abrangentes e avançou muito mais rapidamente dentro da sociedade do que a ideia da Química Verde, ou seja, de uma Química direcionada para o bem-estar e a qualidade de vida. Não há como negar que o cenário político difere bastante do que se via há alguns anos atrás e, obviamente guardando as devidas proporções, hoje está em condições mais do que favoráveis para abrigar estes temas e investir na sua concretização, mesmo considerando que a reunião de Copenhague entre países, ONGs e cientistas tenha sido frustrante. Não é redundante afirmar que os danos ambientais e as mudanças climáticas podem acarretar destruições, incalculáveis em qualquer modelagem que se utilize.

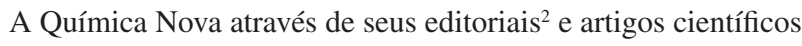
e, de forma geral, as Reuniões Anuais da SBQ têm contribuído para o significativo avanço destes dois temas. Em 2009 a Química Nova dedicou todo o número 3 para tratar de assuntos que envolvem, dentre outros, a inovação e o aproveitamento sustentável de recursos naturais para alimentos, biomassas como fontes de intermediários químicos e produção de energia e os aspectos relacionados com economia, biodiesel e sua cadeia, uso da biodiversidade buscando a descoberta de fármacos e recursos humanos. A educação ocupa papel-chave no processo de uma Química Sustentável, conforme destaca o artigo "Recursos humanos para novos cenários", ${ }^{3}$ onde os autores afirmam: "a interdisciplinaridade e a sustentabilidade devem estar presentes durante todo o processo de formação do Químico, pois delas depende a criação do comportamento verde".

Recentemente, o Centro de Gestão e Estudos Estratégicos (CGEE) colocou no seu sítio o documento "Química Verde no Brasil 20102030", ${ }^{4}$ como parte de uma ação do MCT que envolve a produção limpa de bens, reciclagem e Química Sustentável. É interessante notar que o cerne deste documento está dentro do nosso primeiro editorial de 2010: "O que é sustentabilidade?". ${ }^{5}$ Ele considera a "necessidade de adequar o país para novos paradigmas da economia da sustentabilidade baseada no uso de matérias-primas renováveis", ou seja, que a "inovação e competitividade para a indústria brasileira" deveriam estar baseadas em "processos químicos que usam matérias-primas renováveis", o que pode ser considerado uma das vertentes da Química Verde. Em continuação, o documento sugere duas ações que deveriam ser realizadas: "Estruturação de uma Rede Brasileira de PD\&I em
Química Verde" e a "Criação de uma Escola Brasileira em Química Verde". O documento focaliza que as ações deveriam envolver rotas termoquímicas e bioquímicas que poderiam ser exploradas em biorrefinarias para o desenvolvimento de bioprocessos e bioprodutos, o uso de biocombustíveis e energias alternativas, a exploração de novas rotas para a alcoolquímica, oleoquímica e sucroquímica, que aproveita recursos naturais da flora e o $\mathrm{CO}_{2}$ como matérias-primas.

Como pode ser observado nos resumos apresentados acima, o documento do CGEE e os artigos publicados na QN n. 3 (2009) apontam para a mesma direção, apenas com pequenas variações no seu conteúdo. Há convicção de que se deve adotar uma nova matriz energética menos poluente, a partir de fontes renováveis, em substituição ao petróleo e combustíveis fósseis e que devem ser desenvolvidas novas tecnologias para o aproveitamento da biomassa para produção de intermediários químicos e novas matérias mais eficientes e biodegradáveis. Ambos apontam que há saídas inteligentes para a sociedade, mesmo diante de prognóstico sombrio de escassez de recursos naturais e ameaças de extinção de espécies animais e vegetais, desde que ações sejam tomadas. Os artigos publicados na QN n. 3 (2009) fazem diagnósticos e prognósticos para uma Química Sustentável. O documento do CGEE faz um diagnóstico e propões duas ações, mas não explicita quando e como essas ações serão implementadas.

Está na hora do Brasil ter um plano estratégico nesta área, tendo em vista que a própria população já está bem sensibilizada com os problemas da sustentabilidade, mas não sabemos até onde esta preocupação significa renúncia a alguns velhos hábitos socioambientais bem conhecidos. Porém, palavras devem ser transformadas em ações efetivas.

Estas não são as únicas ações dentro do complexo e diversificado panorama da sustentabilidade. Ainda há muito a avançar nesta direção, pois só temos um planeta e o futuro não pode esperar.

Susana I. Córdoba de Torresi Vera L. Pardini Vitor F. Ferreira Editores de QN

\section{REFERÊNCIAS}

1. de Torresi, S. I. C.; Pardini, V. L.; Ferreira, V. F.; Quim. Nova 2010, 33,5 .

2. Galembeck, F.; Pardini, V. L.; Quim. Nova 2009, 32, 565.

3. Pinto, A. C.; Zucco, C.; de Andrade , J. B.; Vieira, P. C.; Quim. Nova 2009, 32, 567.

4. http://www.cgee.org.br/atividades/redirect.php?idProduto $=6528$, acessada em Agosto 2010.

5. Ferreira, V. F.; Quim. Nova 2001, 24, 165. 